\title{
THE EVIDENCE OF ANONYMOUS WITNESSES IN CRIMINAL COURTS: NOW AND INTO THE FUTURE
}

\author{
Alan George Ward ${ }^{*}$
}

\begin{abstract}
Anonymous witness evidence, the use of which had quietly expanded in the early part of the twenty-first century in criminal courts in England and Wales, was significantly curtailed by the House of Lords in the case of $R v$ Davis. ${ }^{1}$ Little over a month later the government had enacted legislation to minimise the impact of their Lordships' ruling, yet the long-term future of this area of the criminal law of evidence remains undetermined.

This article seeks to assess what impact the Criminal Evidence (Witness Anonymity) Act 2008 has had on the right to a fair trial in England and Wales and, subsequently, to weigh up the options for long-term reform in this area of the law. It will be submitted that the stated policy aim of the government, the protection of witnesses, can be achieved for the long-term without impeding or undermining the absolute right of the defendant to a fair trial.
\end{abstract}

\section{INTRODUCTION}

Lord Bingham has dated the debate surrounding anonymous accusation back to Ancient Rome, the Inquisition and Star Chamber in Tudor England. ${ }^{2}$ In the 1970s a Commission under Lord Diplock reached the same conclusion: that concealing witnesses' identities, and thus removing the right of the accused to confront his accusers, was not appropriate to combat even the thensevere danger of paramilitary intimidation. ${ }^{3}$

Yet for all this long history, thirty-three days in the summer of 2008 will be remembered as being pivotal in the history of the rights of the accused and, more fundamentally, the right a fair trial in England and Wales. This article is

\footnotetext{
* Student member of the Honourable Society of Lincoln's Inn.

${ }^{1} R$ v Davis [2008] 1 AC 1128.

${ }^{2}$ Ibid, at para [5].

3 "Report of the Commission to consider legal procedures to deal with terrorist activities in Northern Ireland” HMSO, 1972, Cmnd. 5185.
} 
not exclusively concerned with rehearsing the details of this short period but instead seeks to look ahead and assess what is next for the rights of defendants in our criminal justice system, which previously stood strong through the difficulties of previous generations.

On June $18^{\text {th }} 2008$ the Appellate Committee of the House of Lords gave judgment in the case of $R v$ Davis. The appellant Iain Davis had been convicted of a double murder at an all-night party on New Years Eve 2002. At trial Davis was convicted following testimony of three witnesses who alone were able to identify him as the gunman. Owing to their fear of reprisals following any testimony these critical prosecution witnesses were granted a host of special measures to conceal their identity from the defendant and his legal team.

The three witnesses were concealed from sight of the defendant by screens and had their voices electronically distorted. Their names and other potentially identifying details were concealed and the defendant's legal representatives were not able to ask the witnesses any questions which might have led to the revelation of their identities. The witnesses against Davis were anonymous and their testimony decisive. Those who gave the decisive testimony against him, Davis alleged, did so with the desire to see him convicted, yet defence counsel were not able to explore this allegation. ${ }^{4}$ As a result of the protection afforded to his accusers Davis was not able to conduct his defence fully and at trial he was convicted of double murder. An appeal against conviction was lodged.

Though the name of Davis is and will remain most closely associated with the debate surrounding anonymity of witnesses, his appeal to the Court of Appeal, and ultimately to the House of Lords, was heard alongside a similar case of arguably greater notoriety. In March 2005 the murder convictions of Marcus Ellis and others for shooting dead Leticia Shakespeare and Charlene Ellis in a gang-related murder in Birmingham were handed down following a trial in which the evidence of one anonymous witness for the Crown, "Mark Brown," proved contentious but ultimately decisive. "Mark Brown" had his name and true identity withheld from the defence and jury, gave evidence behind a screen and had his true voice distorted and played to the court on a time delay. Brown was known to be a convicted criminal and self-confessed rival gang member. Yet he remained otherwise wholly anonymous. As Nigel Rumfitt QC stated in his closing speech for the defence, "As far as we are aware, no witness has ever been allowed to give evidence in the way Brown was in the entire history of our common law going back the best part of 1,000

\footnotetext{
${ }^{4}$ Iain Davis alleged that his anonymous accusers included his ex-girlfriend and her new boyfriend. Any defence cross-examination as to the anonymous witnesses' motives, or which would lead to their identity being revealed, were strictly proscribed at trial.
} 
years." ${ }^{5}$ Media reaction to this verdict recognised that the fundamental reliance placed by the Crown on anonymous testimony had marked a "legal precedent." 6

On appeal to the Court of Appeal in 2006 the special measures granted at the trials of Davis and Ellis were deemed to have had basis at common law and were adjudged to have been applied in a manner consistent with the right to a fair trial, guaranteed by Art 6 of the European Convention on Human Rights. $^{7}$ Subsequently the trials of Iain Davis and Marcus Ellis were deemed to have been fair and their respective convictions for murder were upheld. Leave to appeal was initially refused by the Court of Appeal, before being granted by their Lordships in the House of Lords on October $10^{\text {th }} 2006$.

On June $18^{\text {th }} 2008$ the House of Lords reached the opposite conclusion to that of the Court of Appeal and in allowing the appeal of Davis and others, handed down a judgment that was to capture attention in government and Parliament and bring the law of criminal evidence to the front pages of the tabloid press. The House of Lords unanimously ruled in $R v$ Davis $^{8}$ that a conviction, based solely or to a decisive extent on the testimony of anonymous witnesses, was unsafe, and that such a means of conviction was incompatible with Art 6 (3) (d) of the European Convention on Human Rights. ${ }^{9}$

\section{R V DAVIS: THE EUROPEAN DIMENSION}

Lord Mance, in his speech in Davis, examined in some detail the jurisprudence of the European Court of Human Rights on matters of and relating to the human rights compatibility of State reliance on anonymous testimony in criminal proceedings with the defendant's absolute right to a fair trial. Of particular importance was the case of Doorson $v$ The Netherlands, a case which Lord Mance read and applied in a manner distinct to that of the Court of Appeal previously. ${ }^{10}$ In the Court of Appeal it was held that the "essential question" in Doorson had been "whether the proceedings were unfair." Lord Judge, in the Court of Appeal, stated: "Notwithstanding the

\footnotetext{
5 “Murder Trial Sets Legal Precedent” BBC News Online: http://news.bbc.co.uk/1/hi/england/west_midlands/4357759.stm.

${ }^{6}$ Ibid.

${ }^{7} R$ v Davis [2006] 4 All ER 648.

${ }^{8} R$ v Davis [2008] 1 AC 1128 .

${ }^{9}$ Article 6(3)(D) "The European Convention for the Protection of Human Rights and Fundamental Freedoms": The accused has the minimum right "to examine or have examined witnesses against him and to obtain the attendance and examination of witnesses on his behalf under the same conditions as witnesses against him.”.

${ }^{10}$ Doorson v The Netherlands (1996) 22 EHRR 330.
} 
significance to the conviction of the evidence of two anonymous witnesses, in Doorson the conclusion was that [proceedings] were not [unfair]."11

The Court of Appeal interpreted the case of Doorson as authority for the proposition that the "essential question" for the Strasbourg Court in determining whether the right to a fair trial was violated was whether proceedings were rendered "unfair." Doorson was also treated by the Court of Appeal as a precedent, showing the Strasbourg Court unwilling to deem a trial where anonymous testimony was used to secure conviction as unfair or amounting to a breach of the accused's Art 6 right.

Lord Mance in the House of Lords, however, appears to have read the case of Doorson differently. Firstly, the matter of whether "proceedings as a whole...were fair" is described in Lord Mance's speech not as "the essential question" but instead as merely "a starting point."12 Secondly, Lord Mance attaches little weight to the outcome of the case of Doorson, treating it not as an example of the European Court of Human Rights finding anonymous evidence as being generally acceptable, but as "a conclusion difficult to follow on the facts." 13 Thirdly, Lord Mance highlights the proposition of European Human Rights law, found in Doorson, which was to determine the appeal of Davis ultimately successful. His Lordship quotes the judgment of the Strasbourg court as follows:

"Finally, it should be recalled that, even where 'counterbalancing' procedures are found to compensate sufficiently for the handicaps under which the defence labours, a conviction should not be based either solely or to a decisive extent on anonymous statements." 14

Although the jurisprudence of the European Court does not proscribe the use of anonymous testimony entirely, emphasis is placed on the provision of "counterbalancing measures" to ensure a degree of fairness, compatible with the absolute Art 6 right. Such measures were, it seems, absent in the case of Davis. More particularly, Lord Mance highlights the "sole and decisive evidence” principle as the appropriate test which the Strasbourg Court applies in cases concerning anonymous witness testimony in order to determine whether such trials are fair, within the meaning of Art6. Accordingly, if anonymous evidence, which handicapped the defendant's Art 6(3)(d) right to examine his accusers, was the "sole and decisive" reason for conviction then the European Court of Human Rights would most likely deduced, find a violation of the Convention. Lord Mance concluded that the Strasbourg Court

\footnotetext{
${ }^{11}$ Above $n$ 7, Sir Igor Judge P at para [38].

12 Above n 8, Lord Mance at para [75].

${ }^{13}$ Ibid, at para [77].

${ }^{14}$ Ibid, at para [80]. Lord Mance citing Doorson $v$ The Netherlands at para [76].
} 
would not have found the trial of Davis to have been fair; the murder conviction had been based to a decisive extent on the evidence of Davis's anonymous accusers, evidence which could not be properly tested by the defendant or counterbalanced by other measures.

\section{R V DAVIS: THE COMMON LAW DIMENSION}

The House of Lords decision in $R v$ Davis was unanimous on the matter of breach of the appellant's Art 6 rights, but closer analysis of their Lordships' individual speeches reveals a multiplicity of views on the status of witness anonymity at common law. Whereas the Court of Appeal decisively stated that there existed "clear jurisdiction at common law to admit incriminating evidence given against the defendant by anonymous witnesses" their Lordships did not attempt to formulate any such conclusion on the common law position. ${ }^{15}$ There appears to be a general acceptance by their Lordships of the existence of a common law power to grant witnesses anonymity, but with the qualification that any such power is limited to operation within the parameters established in $R v$ Murphy (which are discussed in detail below). ${ }^{16}$ Only Lord Roger of Earlsferry approaches a position of denial of any common law power to grant witness anonymity, stating, "the appellant's trial did not meet that standards required by Art 6 of the European Convention. In the circumstances it is unnecessary to decide whether the decision in $R v$ Murphy is consistent with the common law."17

As Lord Mance concluded, in light of the incompatibility of the degree of anonymity granted to Crown witnesses at the trial of Davis with Art 6, any common law power for Courts to grant such anonymity had been manifestly exceeded. Their Lordships declined to extend an uncertain common law power to the point where the defendant's right to test the evidence against him was prejudiced, and extended an invitation to Parliament to clarify the law through statute. Parliament ultimately was to accept their Lordship's invitation to abolish the common law rules regarding anonymity and replace them with a statutory scheme, in the Law Reform (Witness Anonymity) Act $2008 .^{18}$

\footnotetext{
15 D Howarth “The Criminal Evidence (Witness Anonymity) Act 2008” Archbold News (2008) pp 6-9.

${ }^{16} R v$ Murphy [1990] NI 306, CA NI.

${ }^{17}$ Above note 1, at para [44].

${ }^{18} \mathrm{~S}$ 1(2) of the 2008 Act states "the common law rules relating to the power of a court to make an order for securing the identity of a witness in criminal proceedings is withheld from the defendant are abolished.”
} 
The effects of their Lordships' judgment in Davis were quickly and widely felt. On June $24^{\text {th }} 2008$ His Honour Judge Paget at the Central Criminal Court suspended a high-profile murder trial, involving anonymous testimony by prosecution witnesses, near to the close of the Crown's case. Further such trial collapses were feared and the Appellate Committee of the House of Lords was roundly blamed. "Chaos as the Law Lords Ruin Trials" was the verdict of one mass circulation tabloid newspaper. ${ }^{19}$

With the press stirring fears that "terrorists, murderers and violent criminals will escape justice" ${ }^{20}$ the Government pledged emergency legislation, and by July $21^{\text {st }} 2008$, only thirty-three days after the decision in $R$ $v$ Davis the Criminal Evidence (Witness Anonymity) Act 2008 was on the statute books and in force. This Act was only enacted as a short-term measure. Those who argued for a "Sunset Clause" as the Bill passed through Parliament were successful and the long-term future of anonymous testimony in criminal courts in England and Wales remains uncertain. ${ }^{21}$ This article seeks to look into the future and assess the extent to which the evidence of anonymous witnesses is desirable in the courts of England and Wales and how such evidence may be fairly balanced with the fundamental right of the accused to test the evidence against him.

It will be argued that witness anonymity orders, as per the 2008 Act, must be a measure of last resort in the criminal courts, and even when used must be subject to rigorous independent scrutiny. Whereas the witness who has absolutely no prior knowledge of the defendant, his associates or the context of the alleged offence may, exceptionally, prove suitable for anonymity those with a propensity or motive to lie, or a grudge to settle, such as "Michael Brown”, must be denied any such measures as would handicap the conduct of the defence. This approach, it will be argued, will enable our system of criminal justice not just to pursue an approach "consistent with" the rights of the accused, but to place such rights at the forefront of our endeavours to achieve justice openly and fairly, through the evidence-based conviction of the guilty.

\section{“CREEPING EMASCULATION”: THE ROAD TO $R$ V DAVIS}

As was noted above, the use of anonymous witnesses was deemed a step too far in the 1970s, even in the face of paramilitary violence in Northern Ireland. It is therefore worth briefly noting how the use of such testimony to secure conviction in the criminal courts of England and Wales reached the

\footnotetext{
19 "Chaos as the Law Lords Ruin Trials" The Sun (June 25 "2008).

20 "Murders will escape justice without new laws to end 'secret witness' ban, warns Straw” The Daily Mail (June $25^{\text {th }} 2008$ ).

21 “Sunset Clause” s 14 Criminal Evidence (Witness Anonymity Act) 2008.
} 
point by summer 2008 when their Lordships were forced to declare "the creeping emasculation of the common law principle must not only be halted but reversed., 22

The right of the accused to come face to face with his accuser was arguably first amended by the Criminal Justice Act 1988, s 32 of which permitted the giving of evidence via video link. ${ }^{23}$ More recently sections 1635 of the Youth Justice and Criminal Evidence Act 1999 saw the introduction of various "special measures" to further keep vulnerable witnesses from having to face a defendant. ${ }^{24}$ However, these modifications to the strict right of confrontation do not allow for the concealment of identities. The ethos of these changes was the protection of the vulnerable victim. The measures inflict minimal, if any, prejudice on the defendant. They can not properly be deemed part of the "creeping emasculation" of the common law right of confrontation which their Lordships in Davis highlighted.

It was through case law that the "creeping emasculation" truly began, and it is through case law that the defendant's common law right to confrontation can be seen to have been gradually eroded. ${ }^{25}$ The 1990 case of $R v$ Murphy saw anonymity being granted to television cameramen who had photographed a murder. ${ }^{26}$ Their evidence did not implicate the defendant and their credibility as witnesses was not in issue. The degree of anonymity granted at trial was slight; the photographers gave testimony behind a screen. They testified merely to confirm that they took the relevant photographs. As was discussed above, their Lordships in the House of Lords declined to firmly conclude whether the case of Murphy was rightly decided, and by extension, whether a common law power to grant witnesses anonymity flowed from this case. What can be concluded, however, is that Murphy may be taken to represents the clearest starting point for the admissibility of anonymous testimony in criminal trials, judicial understanding of which was to culminate in the vast array of special, identity-concealing measures granted to the pseudonym-witness "Michael Brown" in 2005, which proved such a severe handicap to the conduct of Marcus Ellis's defence.

\footnotetext{
${ }^{22}$ Lord Brown of Eaton-Under-Heywood in Davis at para [66], the "common law principle" being the right of the defendant to face and challenge his accusers.

${ }^{23}$ S 55 Criminal Justice Act 1991 further advanced this innovation.

${ }^{24}$ Witnesses eligible for special measures as a result of being "in fear or distress", as per s 17(1) Youth Justice and Criminal Evidence Act are not entitled to the "special measures" in ss 29 and 30 of the Act, reinforcing the proposition that such measures are aimed at improving the quality of testimony from a truly vulnerable victim.

${ }^{25}$ The outline of important cases here provided is for background purposes only. A more detailed examination of the authorities, and the gradual evolution of the common law stance on the right to confrontation, is provided by Lord Bingham in his speech in Davis.
}

${ }^{26}$ Discussed in greater detail in Davis at para [12]. 
Following the case of Murphy judicial acceptance of the ability to grant witness anonymity continued with the case of $R v$ Taylor \& $\mathrm{Crab}^{27}$ at the Central Criminal Court in 1994. At the murder trial of Taylor and Crab a witness to the alleged murder, known as "Miss A", was granted anonymity as she gave her testimony. Crucially, however, the defendants saw "Miss A" on CCTV, in case she was known or recognisable to them.

The 1993 case of $R v$ Watford Magistrates Court ex parte Lenman ${ }^{28}$ was cited by the Court of Appeal in their consideration of the first appeal of Davis as evidence of a "clear jurisdiction at common law to admit incriminating evidence given against the defendant by anonymous witnesses." ${ }^{29}$ The Watford case concerned a number of youths accused of violent disorder; witnesses were only willing to give evidence under pseudonyms, behind screens with their voices concealed, a set of special measures which Magistrates had acquiesced with for the purposes of committal proceedings. In upholding the special measures regime, the magistrates had approved Bedlam LJ went so far as to describe the power of courts to withhold witnesses' identities as "well established." 30

As late as 2003, the protection afforded to the accused, though the common law right of confrontation, was alive and well. In the judgment of Hughes $\mathrm{J}$ in $R v$ Aston Bola anonymity for a witness in a drug-related murder case was refused. ${ }^{31}$ Lord Bingham in Davis highlighted this judgment as "a model of fairness". ${ }^{32}$ The case of Aston Bola, however, represents something of a watershed. It was only in certain criminal trials after 2003 that the granting of anonymity by Crown Court judges to critical, incriminatory prosecution witnesses became problematic. Such trials included those of Iain Davis at the Central Criminal Court in May 2004 and that of Marcus Ellis in early 2005.

From 1990, the year that saw the anonymous testimony of the photographers of a murder deemed acceptable, to 2005, when the heavily disguised "Michael Brown" took to the witness box, the "creeping emasculation" of the common law right of confrontation is clearly visible. The House of Lords was to find in 2008 that the expanding utilisation of anonymity for witnesses giving the "sole or decisive testimony" against a defendant represented an unacceptable violation of the common law right of

\footnotetext{
${ }^{27} R v$ Taylor \& Crab, reported in The Times $\left(17^{\text {th }}\right.$ August 1994) CA.

${ }^{28} R v$ Watford Magistrates Court ex $p$ Lenman 1993 Crim LR 388, cited in $R v$ Davis [2006] at para [27]. The case is considered by Lord Bingham in the House of Lords, at para [13] of Davis [2008].

${ }^{29} R v$ Watford Magistrates Court ex p Lenman [1993] Crim LR 388.

${ }^{30}$ Ibid.

${ }^{31} R v$ Bola (unreported) 18 June 2003.

${ }^{32} R v$ Davis [2008]. Lord Bingham at para [34].
} 
the accused to confront his accusers, as well as being a measure incompatible with Art 6(3)(d) of the European Convention on Human Rights. Their Lordships handed down their ruling in Davis on June $18^{\text {th }} 2008$. By July $21^{\text {st }}$, however, the Government had reacted.

The critical questions this article will now turn to address are: firstly, whether the Criminal Evidence (Witness Anonymity) Act 2008 creates a satisfactory safeguard of the rights of the accused and his right to a fair trial and, secondly, what statutory measures may follow the 2008 Act to better safeguard and advance these fundamental human rights, upon which our system of criminal justice is based.

\section{THE “WITNESS ANONYMITY” ACT 2008: A SATISFACTORY SAFEGUARD OF THE RIGHTS OF THE ACCUSED?}

The new Act was widely feared following the decision in Davis. Unfavourable comparisons were drawn early on with other legislation passed through Parliament on such a short timescale. ${ }^{33}$ "If government acts in haste, it may well repent at leisure" was typical of the concern voiced by commentators on all sides. ${ }^{34}$

In the furore that followed their Lordships' decision in Davis the government's wish for swift legislation was clear. The first set of explanatory notes to the Witness Anonymity Bill, issued on July $3^{\text {rd }} 2008$, stated that the intended purpose of the Bill was to "restore the law to, broadly, the position it was believed to be prior to Davis." 35 The Government, it seems, was content with the so-called "creeping emasculation" of the defendant's right of confrontation; convictions in high-profile shooting cases are, it must be remembered, popular with the voting public. In haste, it seems the Government's prime concern was to prevent the collapse of ongoing cases involving anonymous testimony, even if this meant sacrificing the concerns for the rights of the accused which their Lordships in Davis had highlighted.

Yet the legislation that emerged on the statute books on July $21^{\text {st }} 2008$ seems to acknowledge the concerns for the right to a fair trial that their Lordships had raised. The Witness Anonymity Act cannot be viewed as a wholesale departure from the European Convention, or even as a reversal of their Lordships' decision in Davis. Intriguingly, it is almost certain that Davis would have been decided the same way under the principles of the new

${ }^{33}$ Liberty, at para [18] of their Briefing on the Criminal Evidence (Witness Anonymity) Bill 2008 concluded that "the history of rushed legislation is not a good one" drawing attention in particular to the Dangerous Dogs Act 1991 and Part 4 of the Anti-Terrorism, Crime and Security Act 2001.

${ }^{34}$ I Kelcey "Panic and Rough Justice” Law Society Gazette July $17^{\text {th }} 2008$.

35 “Explanatory Notes” July $3^{\text {rd }} 2008$ para [50]. 
legislation. ${ }^{36}$ Indeed, it is clear that the Government has strived to incorporate into the Witness Anonymity Act measures and the safeguards to ensure compatibility with the European Convention on Human Rights. The Parliamentary Joint Committee on Human Rights reached the same determination as the Bill passed through Parliament. ${ }^{37}$

As was noted above section 1(2) of the Witness Anonymity Act abolished the common law rules "relating to the power of a court to make an order for securing the identity of a witness in criminal proceedings is withheld from a defendant." ${ }^{38}$ The 2008 Act is thus now the sole authority under which a criminal court may grant a witness special measures to conceal identity. Section 3(2) of the 2008 Act details the measures a criminal court may grant a witness in order to achieve this aim; witnesses remain able to give evidence under pseudonyms, behind screens and with their voices electronically modulated or distorted. ${ }^{39}$ Section 2(2(a) of the Act allows prosecutors to withhold the identity of anonymous witnesses from the defence, by way of excluding any potentially-identifying detail from normal prosecution disclosure. This provision of the 2008 Act, although necessary to achieve the stated aim of concealing identities fully, constitutes one of the principal challenges to the right of the accused to challenge his accusers. Scrutiny of Crown witnesses, on the critical issues of motive and credibility, is largely left to prosecutors, a difficulty discussed at greater length below.

Further detrimental to the common law right of confrontation is section $3(2)(c)$, which proscribes "questions of any specified description that might lead to the identification of the witness." This provision puts a clear bar on potentially probative lines of cross-examination, which may often be vital to the conduct of a defendant's case. Under the 2008 Act, then, an anonymous witness, scrutinised solely by the Crown, may avoid difficult questions from defence counsel with impunity.

Section 3 of the Witness Anonymity Act deals with the manner in which applications for anonymity orders must be sought. Even in this initial procedure there appears to exist an inherent (although it is submitted not a serious) inequality between prosecution and defence applications. Section 3(2) allows the Court to rule that the prosecution may conceal the identity of a

\footnotetext{
${ }^{36}$ A conclusion widely expressed among commentors following the passage of the 2008 Act: See Liberty Briefing on the Criminal Evidence (Witness Anonymity) Bill 2008 para [14].

37 JCHR: Legislative Scrutiny: Criminal Evidence (Witness Anonymity) Bill. TwentySixth report of session $2007-2008$. July $15^{\text {th }} 2008$.

${ }^{38}$ Criminal Evidence (Witness Anonymity) Act 2008, s 1(2).

39 Criminal Evidence (Witness Anonymity) Act 2008, s 3(2)(b) allows for pseudonyms, 3(2)(d) allows for screening and s (3)(2)(e) for voice modulation "to any specified extent.”
} 
potential anonymous witness from not only the defence, but even from the Court. In cases where there is a sole defendant, however, section 3(3) forces the defence to disclose the identity of any potential anonymous witnesses for the defence to the prosecution. In a case where a defendant alleges police misconduct or intimidation this inequality, allowing the prosecution to know the identity of all apparently anonymous defence witnesses, may cause such a defendant, or any potentially-key defence witnesses, some difficulty. ${ }^{40}$

Criminal courts may only make a witness anonymity order if the three "Conditions" set out section 4 of the 2008 Act are satisfied. Condition A provides that an anonymity order must be "necessary" to protect the safety of a witness or other person, or to prevent serious damage to property. Alternatively, Condition A can be satisfied if an order is "necessary...in order to prevent any real harm to the public interest." ${ }^{41}$ Condition B states that any anonymity order must be "consistent with" the defendant's right to a fair trial. $^{42}$ Finally, Condition C provides that an anonymity order must be "necessary...in the interests of justice." ${ }^{33}$ An order is necessary in the interests of justice under section 4(5) of the Act if (a) it is important that the witness should testify and (b) the witness would not testify if the order were not made.

Significantly, section 5 of the Act states that a court must have regards to five "relevant considerations", listed at section 5(2), before granting a witness anonymity order in criminal proceedings. ${ }^{44}$ These "considerations" appear to deliberately address concerns which their Lordships expressed in Davis: (a) the general right of a defendant to know the identity of witnesses, (b) the extent to which credibility of a witness is likely to be in issue, (c) whether evidence given by an anonymous witness is likely to be the "sole or decisive" factor in a finding of guilt, (d) whether the defendant is believed to have a tendency to be dishonest or a motive to give false testimony and (e) whether any other method of protecting the witness's identity would be practicable or more appropriate at trial.

Furthermore, $\mathrm{s} 7$ of the Act provides that a direction must be given to the jury at the close of a trial where anonymous evidence has been given to ensure the defendant is not prejudiced in the minds of jurors. Such a measure is a bare minimum requirement; anecdotal evidence reveals the extent to which jurors are influenced by non-evidentiary matters at trial. It is particularly easy to foresee a jury determining, even subconsciously, that a defendant must be a dangerous individual if they are capable of instilling such fear in a witness so

\footnotetext{
${ }^{40}$ Above $n$ 15, pp 6-9.

${ }^{41}$ Criminal Evidence (Witness Anonymity) Act 2008, s 4(3).

${ }^{42}$ Ibid, s 4(4).

43 Ibid, s 4(5).

${ }^{44}$ Ibid, s 5(2).
} 
as the Court deems their identity must be concealed for their safety. ${ }^{45}$ Surely a jury will then determine, albeit subconsciously, that such a "dangerous individual" must be removed from society for the protection of the general public, whether they happen to be guilty of the particular offence(s) charged or not. The mandatory jury direction will, to some degree, alleviate this risk of unfairness in the criminal trial; yet mitigating the risk of unfairness in a criminal trial is surely insufficient. The right to a fair trial, under Art 6 of the European Convention on Human Rights, is an absolute one. The question of whether a jury direction is sufficient to ensure a fair trial for the accused is just one of many such concerns which may reasonably be advanced by those concerned with the future of a fair and just criminal process in England and Wales.

As was noted above, s 5(2) seeks to act as a "safety valve" to ensure judges consider the critical human rights issues that arise from the use of anonymous witnesses before granting any order to permit their use at trial. Yet it is questionable whether the matters listed in this provision should be presented to trial judges with merely the status of "relevant considerations." Some of the considerations, such as the general right of confrontation of one's accusers and the "sole and decisive evidence" test have a status of their own in common law and the jurisprudence of the European Court of Human Rights. ${ }^{46}$ It can be argued that a judge in determining a witness anonymity application should more than merely consider the factors in s 5(2); for the Act to be truly compatible with human rights the judge should be satisfied to a very high standard that a fair trial would follow from the use of any anonymous witness evidence.

If the concerns of their Lordships are taken as largely reflected and nullified through the "relevant considerations" there is one critical concern, raised by Lord Bingham in Davis, which the Act fails to account for. Lord Bingham states that: "the fairness of a trial should not largely depend on the diligent performance of their duties by the prosecuting authorities", yet the Act strives to achieve scrutiny of potential witnesses solely through the disclosure obligations of the Crown. ${ }^{47}$ Section 5(2)(c) of the Act requires the presiding judge to consider the credibility of a potential candidate for witness anonymity in terms of any tendency to be untruthful and any motive they may have to give false testimony against the particular defendant to face trial. Yet

\footnotetext{
${ }^{45}$ Liberty Briefing on the Criminal Evidence (Witness Anonymity) Bill 2008, para [16].

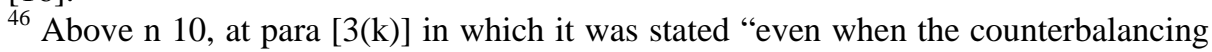
procedures did compensate sufficiently for the handicaps under which the defence laboured, a conviction should not be based to a decisive extent on anonymous statements."

${ }^{47}$ Lord Bingham in Davis at para [31].
} 
all the documentation provided to the court for the undertaking of this consideration is provided by the prosecution. Injustice will occur following such a course. The Attorney General's Guidelines which followed the 2008 Act state that "the role of the prosecutor as an independent and impartial minister of justice is of paramount importance", ${ }^{48}$ yet this assurance represents little by the way of safeguard for a defendant. One ambitious prosecutor, keen to obtain a high profile conviction, or one negligent police officer would be all it would take for the fairness of the scrutiny regime, as presently enacted, to evaporate, taking the fairness of the trial with it. The sponsors of the 2008 Act would dispute the suggestion that any professional associated with the prosecuting authorities would act with anything other than "scrupulous fairness." 49 However, history suggests that there is at least a risk of prosecutors failing to disclose everything which they reasonably could to the defence. The trial of Kieron Fallon for alleged "race fixing” collapsed recently when prosecutors failed to disclose expert reports, which undermined to their case against the jockey. ${ }^{50}$

The issue of inadequate scrutiny of prosecution witnesses exposes the biggest shortcoming of the Witness Anonymity Act. The present inadequacy of the scrutiny regime lends itself to one inevitable solution, which the Act neglects to provide for; the use of independent counsel to test the proposed prosecution evidence for credibility, veracity and admissibility within the parameters of human rights law. The New Zealand Evidence Act 2006 provides for an express statutory discretion for a trial judge to appoint of independent counsel when the court is faced with an application for a witness anonymity order. The full implications and benefits of such an approach are examined in the final section of this article.

The present regime in England and Wales, by way of contrast, does more than omit to provide for such a safeguard and assurance of adequate scrutiny. Sources tangential to the Act go so far as to dismiss such an approach to witness anonymity applications. The Attorney General's Guidelines on witness anonymity procedure note that the Attorney General does have the power to appoint such special counsel, despite no mention being made of such a procedure in the Act. ${ }^{51}$ However, the Guidelines fall back on the ratio of the House of Lords case of $R \vee H \& C,{ }^{52}$ and deem the appointment of

\footnotetext{
${ }^{48}$ Attorney General's Guidelines: The Prosecutor's Role in Applications for Witness Anonymity Orders. Criminal Evidence (Witness Anonymity Act) 2008 para [B4].

${ }^{49}$ Ibid, para [B3].

${ }^{50}$ Kieron Fallon trial $-R v$ Lynch \& Others (2007) unreported. The Times reported the collapse of the "race fixing trial" at the Central Criminal Court on December $8^{\text {th }} 2007$ : http://www.timesonline.co.uk/tol/sport/racing/article3019158.ece.

51 Above n 49, para [D2].

${ }^{52} R v H, R v C[2004] 2$ AC 134.
} 
independent counsel "exceptional, never automatic" and "a course of last and never first resort." 53 The role of the court in assessing the evidence, coupled with the prosecutor's duty to put all relevant material before the court, should be sufficient for "a fair and informed decision to be reached without the need for Special Counsel." 54

Yet the present scrutiny regime for witness anonymity orders remains the most significant threat to the fair trial that arises out of the Witness Anonymity Act 2008. The Act expects the prosecutor to firstly have the ability to look at his evidence with eyes of the defendant and secondly, to be able to perform this task as well and as diligently as a defence team, with full instructions from the accused. Though co-operation between defence and prosecution is increasingly deemed desirable in our criminal justice system the principles of adversary cannot be compromised when it comes to the scrutiny of evidence and the just advancement of the defence case.

The final section of this article will seek to determine how this unsatisfactory situation can be remedied, and to highlight various other models for witness protection that Parliament should at the very least debate before proceeding to replace the present Witness Anonymity Act.

\section{AFTER SUNSET: WHAT NEXT FOR WITNESS PROTECTION AND THE RIGHTS OF THE ACCUSED?}

The Coroners and Justice Bill, introduced into Parliament on $14^{\text {th }}$ January 2009, proposes re-enact the 2008 Law Reform (Witness Anonymity) Act 2008 , which was originally due to expire on December $31^{\text {st }} 2009 .^{55}$ Insofar as they constitute a modification of the measures enacted in July 2008 the proposals in Part 3 of the Coroners Bill for the future treatment of the evidence of anonymous witnesses will be examined below. Consideration will also be given to the Court of Appeal judgment, from December 2008, in $R v$ Mayers, the case that represented the appellate court's first opportunity to interpret and apply the provisions of the 2008 Witness Anonymity Act. ${ }^{56}$

\section{DEVELOPMENT OF THE LAW PART 1: R V MAYERS}

The consolidated appeals of Mayers represent the first reported appeals against conviction emerging in the wake of the Law Reform Witness Anonymity Act 2008. S11 of the 2008 Act provides that an appeal against

\footnotetext{
53 Attorney General's Guidelines: The Prosecutor's Role in Applications for Witness Anonymity Orders. Criminal Evidence (Witness Anonymity Act) 2008 para [D2].

${ }^{54}$ Ibid, para [D2].

55 See Criminal Evidence (Witness Anonymity) Act 2008, s 14.

${ }^{56} R v$ Mayers [2008] EWCA Crim 2989.
} 
conviction may be deemed unsafe if a witness anonymity order was made at trial before commencement of the Act (July 21 $1^{\text {st }}$ 2008) and such an order could not have been made had the Act been in force at the material time. ${ }^{57}$ Additionally, such a pre-commencement order must have meant the defendant "did not receive a fair trial" for an appeal against conviction to succeed. ${ }^{58}$

In the case of Jordan Mayers, a "pre-commencement" case, an appeal against conviction was allowed by the Court of Appeal, and the appellant's conviction for murder was quashed. At his trial, due to start on July $9^{\text {th }} 2007$, the Crown relied on the evidence of an anonymous witness "Jeanette Evans", who purported to identify Mayers as the assailant in a fatal knife attack. However, the existence of this witness was only made known to the defence on $28^{\text {th }}$ June 2008, leaving the time frame for scrutiny of "Jeanette Evans" in terms of credibility and potential motive for testifying short.

Allowing the appeal of Mayers the Court of Appeal concluded as follows:

"Notwithstanding the absence of full and comprehensive inquiries needed to set against the disadvantages created for the appellant by the anonymity order, [Jeanette Evans's] evidence assumed decisive importance in the case against the appellant. Without it a conviction would have been highly improbable.” 59

The appeal thus succeeded because the trial anonymity order would now be incompatible with the Witness Anonymity Act in two important regards. Firstly, the Court of Appeal deemed the evidence of "Jeanette Evans" "decisive". As was noted above the "sole or decisive evidence" test is incorporated into the 2008 Act as a "relevant consideration" which the trial judge must take into account in determining whether the defendant may receive a fair trial. ${ }^{60}$ Secondly, the Court of Appeal found that the prosecution before the trial of Mayers did not adequately test the credibility and character of "Jeanette Evans". Such a lack of investigation would now make satisfaction of sections 5(2)(d) and (e) of the Act, concerning consideration of whether a witness may have any "tendency or motive" to be dishonesty, difficult.

The Court of Appeal has set the requisite standard of investigation into the credibility and motive of potentially anonymous witnesses at a high level. Lord Judge stated in Mayers that should a trial judge "entertain reservations" about the diligence of prosecution scrutiny then an application for witness anonymity under the 2008 Act should be "met with a point blank refusal.,"61

\footnotetext{
${ }^{57}$ Criminal Evidence (Witness Anonymity) Act 2008, s 11(2)(b)(i).

${ }^{58}$ Ibid, s 11(2)(b)(ii).

${ }^{59}$ Above n 56, at para [52].

${ }^{60}$ Criminal Evidence (Witness Anonymity) Act 2008, s 5(2)(c).

${ }^{61}$ Above n 56, at para [10].
} 
The appeal of Junior Glasgow, heard alongside that of Mayers, was refused, however, thus establishing a contrast with the successful appeal of Mayers, illustrative of the dividing line between a safe and unsafe conviction where a witness anonymity application had been granted at trial. The appeal of Glasgow, against conviction for murder, was refused on the basis that firstly, sufficient consideration had been given to the credibility of anonymous trial witnesses and secondly, that the trial judge had considered possible alternatives to making an anonymity order. In contrast to the situation in Mayers, the anonymous witnesses in Glasgow had been identified at an early stage and were thus adequately vetted to ensure independence of one another and lack of motive for testifying against the accused. The judge at the trial of Glasgow was credited by the Court of Appeal as having "anticipated and addresses the pre-conditions to making a witness anonymity order" and, as such, ensured the defendant had received a fair trial. ${ }^{62}$

The final two appeals in Mayers are further usefully illustrative of the application of the 2008 statutory regime. The third appeal, that of Costelloe \& Bahmanzadeh, concerned the admissibility of anonymous testimony at trial from undercover police officers. The evidence of the undercover officers was deemed not to have been the "sole or decisive" evidence against the two appellants, even when "taken cumulatively." 63 There was no suggestion that the officers had any tendency or motive to be dishonest. For these reasons the appeal was dismissed.

The final appeal in Mayers and others, of $V, P \& R$, was not an appeal against conviction but "an interlocutory appeal by the prosecution against a decision on September $19^{\text {th }} 2008$ that the Act did not permit a witness anonymity order to be made unless it was proposed that the witness or witnesses would be called to give evidence." ${ }^{64}$ The Court of Appeal considered whether an anonymity order may be made in respect of an absent witness and, in the alternative, whether it was possible to admit anonymous hearsay evidence. Both questions were answered in the negative, the Court of Appeal declining to re-write the Witness Anonymity Act 2008 or to expand the hearsay provisions of the Criminal Justice Act 2003. ${ }^{65}$

The appeal of Mayers has usefully elucidated the terms of the 2008 Witness Anonymity Act, illustrating through the contrasting cases of Mayers and Glasgow when a trial will be deemed unfair owing to inadequate scrutiny of potential anonymous witnesses. An example of evidence falling short of being "sole or decisive" is provided in the appeal of Costelloe \&

\footnotetext{
${ }^{62}$ Ibid, at para [76].

${ }^{63}$ Ibid, at para [87].

${ }^{64}$ Ibid, at para [2].

${ }^{65}$ Ibid, at para [113].
} 
Bahmanzadeh and anonymous hearsay is expressly excluded from being within the scope of the 2008 Act in the interlocutory appeal of $V, P \& R$.

Further appeals in this sphere will doubtless be heard and reported in the coming months. It is submitted that the Court of Appeal's willingness to quash the conviction of Mayers represents a strong indication that for a witness anonymity application to be granted in the future, trial judges will expect prosecutors to show a significantly heightened degree scrutiny and disclosure relating to such witnesses. Such an enhanced expectation will serve to go some way allay the fears of defence lawyers that where a witness' identity is concealed significant lines of investigation and cross examination, crucial to the conduct of the defence are lost.

\section{DEVELOPMENTS IN THE LAW PART 2: THE CORONERS AND JUSTICE BILL 2009}

On January $14^{\text {th }} 2009$ the Government introduced the Coroners and Justice Bill, Part 3, Chapter 2 of which is intended to replace the Witness Anonymity Act, due to expire on December $31^{\text {st }}$ 2009. At the time of writing the Bill has passed a second reading in the House of Commons (on January $26^{\text {th }}$ 2009), with proposals concerning coroners and inquests attracting more attention through the committee stage and in the media than the provisions relating to the criminal law of evidence. The Bill is due to remain in the Commons committee stage until March $10^{\text {th }}$.

Sections 1-9 and 14 of the Witness Anonymity Act 2008 would be repealed by the Coroners and Justice Bill, though their content is largely reenacted by the provisions, near identical in wording and structure, contained in Chapter 2, Part 3 of the Bill. ${ }^{66}$ Principle among the modifications the Bill seeks to make to the 2008 Statute is the proposed modification of "Condition C", at section 4(5) of the 2008 Act, to remove the word "necessary." ${ }^{67}$ As such, a witness anonymity order would no longer need to be "necessary... in the interests of justice" before being granted. Instead, "Condition C" now merely requires "that the importance of the witness's testimony is such that in the interests of justice the witness ought to testify." 68 The hurdle imposed by "Condition C" appears to be lowered by the proposed legislation. Whether this new phraseology will make a significant difference to trial judges' considerations in deliberating an anonymity order remains to be seen.

Clause 74 of the Coroners and Justice Bill seeks to expand the measures contained in the 2008 legislation on discharge or variation of witness

\footnotetext{
${ }^{66}$ Clause 79 of the Coroners and Justice Bill states: "Sections 1 to 9 and 14 of the Criminal Evidence (Witness Anonymity) Act 2008 (c. 15) cease to have effect.”

${ }^{67}$ Coroners and Justice Bill 2009 clause 71(5).

68 Ibid.
} 
anonymity orders. The new Bill inserts, by way of clause 74(3) a requirement for trial judges to give "every party to the proceedings the opportunity to be heard" before discharge or variation of an order. Clause 74(4), however, allows a prosecution application to be heard in the absence of the defendant and his representatives. The Bill does not provide for a right of appeal against the making, or indeed the refusal of, an anonymity order. As the Explanatory Notes state: "The Government considers that existing appeal procedures are sufficient....In the case of a defendant, the matter may be raised on appeal against conviction." 69 It may be debated whether some form of "fast track" appeal procedure, avoiding significant delay to the trial process, could have been implemented. Taking the case of Davis as a relevant example, an appeal against conviction can take a matter of years to be heard.

The human rights organisation Liberty draws the most fitting conclusion on the provisions of the Coroners and Justice Bill relating to criminal evidence and witness anonymity orders: "While we believe that the provisions in this Bill could be improved on we do not take specific issue with this Chapter." $" 70$ The Bill does not seek to introduce measures which are an added handicap or detriment to the accused, yet neither does seek to make positive advances in the opposite direction. The enhancement of the absolute right of the accused to an absolutely fair trial is not the primary purpose, nor incidental effect of the Bill. This article will now draw to a conclusion by examining how the provisions of the Coroners and Justice Bill 2009 could have established a more satisfactory, long-term solution to the related problems of witness intimidation and the difficulties which arise from the use of anonymous witnesses in our criminal courts.

\section{MOVING TO A LONG-TERM SOLUTION:}

Despite the Government's pledge to revisit the issue of witness anonymity in the present Parliament, as asserted above the Coroners and Justice Bill represents an opportunity missed. As opposed to a piece of legislation specifically designed to address the problem of witness intimidation, whilst giving renewed regard to the rights of the accused, the government seeks to re-enact measures drafted in haste in July 2008, intended then only as an interim solution.

It is submitted that there are three viable proposals for the future of witness protection in England and Wales, which may sufficiently safeguard the rights of the accused and preserve the right to a fair trial into the future. Each of these will now be assessed.

${ }^{69}$ Coroners and Justice Bill Explanatory Notes, issued January $14^{\text {th }}$ 2009, para [436].

${ }^{70}$ Liberty's Second Reading Briefing on the Coroners and Justice Bill in the House of Commons para [47]. 


\section{(a) The Independent Counsel / New Zealand Model}

In similar fashion to England and Wales, New Zealand passed witness anonymity laws following decisions in the appellate courts which affirmed the defendant's absolute right to confront his accusers. ${ }^{71}$ The resulting New Zealand Evidence Act 2006 sought to allow for anonymous testimony in criminal courts in certain, limited circumstances. The provisions of the New Zealand Act are markedly different in two critical regards to the provisions presently enacted in England and Wales. It is submitted that both of these differences in approach taken by the New Zealand statute should form part of any future domestic legislation on the use of anonymous witnesses.

The first difference of approach taken in the New Zealand Evidence Act concerns how widely witness anonymity orders should be granted. Section 110 (1) of the New Zealand Act states that such an order may only be granted where "a person is charged with an offence and is to be proceeded against by indictment." "72 Although the case of $R v$ Davis may lead domestic observers towards the conclusion that anonymity orders are to be the sole preserve of cases concerning only serious, indictable-only offences such as murder, there is nothing in the 2008 legislation which restricts the granting of an anonymity order to certain categories of serious offences. The considerations to be taken into account by a New Zealand judge before granting an anonymity order are listed in section 110 (5) of the 2006 Act. The third of six considerations listed is "the gravity of the offence."73 Again, it is clear that the New Zealand legislation seeks to limit the use of anonymous testimony to the most serious indictable offences.

This is a step that any future legislation must take, so as to avoid the widespread handicapping of defendants throughout the criminal justice system. As soon as the prosecuting authorities are able to offer potential witnesses anonymity when proceeding with a wide range of offences such witnesses may begin to form the view that anonymity is their entitlement, and only acquiesce to give evidence on the condition that they remain anonymous. The Attorney General in his Guidelines on anonymity orders acknowledges that seeking such an order is a "serious step", ${ }^{74}$ but if such testimony is to be allowed in the courts of England and Wales it must firmly remain an exception, as opposed to moving towards the status of a rule.

The second difference of approach which makes the New Zealand model a better safeguard of the rights of the accused is the provisions relating to

\footnotetext{
${ }^{71}$ See $R v$ Hughes [1986] 2 NZLR 129 and $R v$ Hines (unreported) Court of Appeal August $15^{\text {th }} 1997$, CA 465/96.

${ }^{72}$ New Zealand Evidence Act 2006, s 110(1).

${ }^{73}$ New Zealand Evidence Act 2006, s 110(5)(c).

${ }^{74}$ Above n 48, para [D1].
} 
"independent counsel." As was noted above, the present arrangement under the 2008 legislation, where the defendant is dependent on the diligence of prosecution disclosure to test the credibility of witnessed against him, is roundly unsatisfactory. Such an approach was, it must be remembered, preemptively condemned by Lord Bingham in Davis. ${ }^{75}$

The Law Commission of New Zealand noted in their report on proposed witness anonymity laws that:

"Since an anonymity order necessarily deprives the accused and defence counsel of the normal right to knowledge of the witness's identity, we propose that independent counsel be appointed by the court at public expense, to conduct enquiry into the witnesses truthfulness and reliability and the evidence that the witness will give in the proceedings. The purpose of such an appointment will be to compensate as far as practicable for the disadvantage to the defence occasioned by the order." 76

Such a recommendation became law in the form of section 115 of the New Zealand Act.

Section 115(1)(a) gives independent counsel, appointed at the discretion of the presiding judge, a broad remit to objectively assess both the likely truthfulness of any testimony, which it is proposed should be given anonymously, as well as the need for an anonymity order in the first place. Section 115(2) further provides that the independent counsel must be provided with "all the information relating to proceedings" so as a full assessment of the need for, and possible flaws of, potentially anonymous testimony can be vetted and exposed to the trial judge.

The benefits of such independent counsel are readily determinable by reference to the flaws, discussed above, in the present system in England and Wales of reliance on prosecution disclosure for the maintenance of the fair trial. Although the present domestic framework does not expressly rule out the appointment of independent counsel guidance which has followed the 2008 Act has almost impliedly done so. ${ }^{77}$ Any future legislation which is founded on the premise that anonymous testimony is desirable must expressly provide for independent counsel to conduct the analysis of both the need for and potential flaws of proposed anonymous testimony in any given criminal trial. Further to this the New Zealand model must be followed in terms of expressly limiting the use of anonymous testimony to the Crown Court, and to the few

\footnotetext{
${ }^{75}$ Above n 8, at para [31].

76 Law Commission of New Zealand: Evidence Law: Witness Anonymity-.A Discussion Paper (NZLC PP29, 1997) para [71].

77 See above for discussion of AG Guidelines.
} 
most serious indictable-only offences. Such measures would serve to restore the rights of the accused to prominence in the criminal justice process in contract to the provisions of the 2008 Act, which merely see that such rights are taken into account and balanced against other considerations.

\section{(b) The "Enhanced Disclosure" Model}

Should the government seek to develop rather than overhaul the 2008 Criminal Evidence (Witness Anonymity) Act it is possible that the disclosure obligations of the prosecution may be enhanced, to provide a greater degree of scrutiny of proposed witnesses against the accused. Philip Katz QC first mooted such a proposal, requiring prosecutors not only to fulfil their existing obligations of disclosure under the Criminal Procedure and Investigation Act 1996, but to also undertake an active search for material which may undermine witness credibility or the need for anonymous witness order. ${ }^{78}$ The attraction of such a proposition from the government's perspective is clear; a complete overhaul of the 2008 Act would be unnecessary. The Government could reinforce its human rights credentials by claiming to augment the rights of the accused through enhancing the burden of disclosure on the prosecution, indeed creating a burden of active investigation.

The Court of Appeal in $R v$ Mayers recently made some encouraging remarks about the degree of diligence which will be expected of prosecutors when seeking an anonymity order. The Lord Chief Justice stated in Mayers:

"Our approach to this issue enables us to highlight that the obligations of the prosecution in the context of a witness anonymity application go much further than the ordinary duties of disclosure. As we shall see when we examine the statutory considerations a detailed investigation into the background of each potential anonymous witness will almost inevitably be required."

It was on the basis of inadequate scrutiny of the witness "Jeanette Evans" that the appeal of Jordan Mayers was allowed. The Court of Appeal also restated the importance of the defence statement, though, which "must help inform and focus the disclosure process" ${ }^{80}$, particularly in light of the

\footnotetext{
${ }^{78}$ Philip Katz QC interviewed on the BBC Radio 4 programme "Law in Action” June $24^{\text {th }} 2008$.

${ }^{79}$ Above note 56, at para [10].

${ }^{80}$ Ibid, para [12].
} 
enhanced content requirements for such statements, in force from November $3^{\text {rd }} 2008 .^{81}$

Yet the fact remains that for a fair trial to take place the defence must be the party which scrutinised the proposed evidence. A defendant cannot be expected to rely on prosecutors to provide his defence for him. If it is accepted that extra scrutiny must be made mandatory before witness anonymity can be granted then independent counsel may as well perform the extra work this would entail, charged to act with objectivity and the fairness of proceedings at the forefront of their mind, as opposed to securing a conviction. Again it bears repeating: a prosecutor cannot assess the credibility of a witness in the same way as a defendant, who may know or recognise the potential witness, or consider them an enemy, can. If the defence in crossexamination cannot test evidence the defence prior to admission at trial must test it. Failing even this, independent counsel must perform the test if the bear minimum of fairness in the criminal trial is to be upheld.

\section{(c) The "Witness Protection"/International Model}

Prior to drawing conclusions as to the future of this contentious area of the criminal law it is worth considering whether our courts should allow, or indeed whether we have a genuine present need for, anonymous testimony in criminal courts.

The media frenzy, which followed the law lord's decision in Davis, demonstrates the popular sentiment that dangerous criminals should be convicted by whatever means possible. ${ }^{82}$ The government argue, and will continue to argue, that the law must exist to protect the innocent. It can be shown that witness intimidation is rife in England and Wales, with convictions for such having doubled in number between 1996 and $2005 .^{83}$

However, even if it is accepted that witness intimidation is a real and severe threat to the administration of criminal justice in England and Wales it is still arguable whether interference with the trial process, and consequentially the fairness of the trial and the rights of the accused, is the most effective manner in which to address this problem.

It must be noted that the number of countries with judicial systems that have due regard to human rights, which also allow the use of anonymous testimony in criminal courts is small in number. The United States has

\footnotetext{
${ }^{81}$ S 60(1) of the Criminal Justice and Immigration Act 2008 (in force 3/11/08) adds a new s 6A (1) (ca) to the Criminal Procedure and Investigation Act 1996 which requires that a defendant's Defence Statement must set out "particulars of the matters of fact on which he intends to rely for the purposes of his defence."

${ }^{82}$ Above $\mathrm{n} 8$ and 9, with regard to the outrage expressed in the media post Davis.

${ }^{83}$ Lord Carswell raises this statistic in his judgement in Davis at para [52].
} 
enshrined the right of the accused to fully test the evidence against him in their Constitution, the Sixth Amendment stating that "the accused shall enjoy the right...to be confronted with the witnesses against him." ${ }^{84}$ Pursuant to this, the US Supreme Court has vigorously struck down attempts in the lower courts to make inroads into this constitutional right. In Alford $v$ United States $^{85}$ the Supreme Court made a now often-quoted statement:

"The witnesses name and address open countless avenues of in-court examination and out-of-court investigation. To forbid this most rudimentary inquiry at the threshold is effectively to emasculate the right of cross examination itself.," 86

The principle upon which this statement is founded is timeless. A defendant must have the right to defend himself, by testing the evidence against him, a right also encapsulated in Article 6 (3) (d) of the European Convention on Human Rights ${ }^{87}$. Such a fundamental right can not be "balanced" with any other considerations, even the deemed "public interest" in protecting witnesses from fear. It can not be in the long term public interest to downgrade the right to a fair trial.

It is not only the United States which rejects the notion of witness anonymity. The South African courts have resisted attempts to encroach upon the right of confrontation, most notably in the leading case from 1986 of $S v$ Leepile. ${ }^{88}$ Such was the force of this case that there have been no further cases on witness anonymity in South Africa since. In addition to the United States and South Africa the forty-seven Council of Europe countries also reject the need for anonymous testimony as a weapon against witness intimidation.

The government would certainly have a more difficult task of persuading the public that witness anonymity is necessary here if it were made clear just how isolated the 2008 Act makes our position in a global context. It cannot be convincingly argued that serious gang crime and witness intimidation is worse in London or Birmingham than it is in New York, Italy or on the streets of Johannesburg or Bloemfontein.

\footnotetext{
84 “The Constitution of the United States” Amendment 6. (Ratified 1791).

${ }^{85}$ Alford v United States 282 US 687 (1931).

${ }^{86}$ Ibid.

87 “The European Convention on Human Rights and Fundamental Freedoms” Art 6 (3)(d).

${ }^{88}$ S v Leepile:(5)1986(4)SA187(W). In this case Ackermann J refused an application by the prosecutor to allow the true identity of a witness to be withheld, ruling that such must be disclosed to the defence. Of particular interest was Ackermann J's finding that granting anonymity to a witness might "heighten the witness's sense of impregnability and increase the temptation to falsify or exaggerate” at para [189].
} 
As opposed to interfering with the trial process, and as a consequence the rights of the accused, the weapon many of the above mentioned states employ to combat the menace of witness intimidation is large-scale, well funded witness protection programmes. The goal of ensuring potential witnesses are not too fearful to testify in criminal courts is achieved by providing them with the option of a new identity and new home, hidden far from any danger of reprisal following their testimony. Evidence from other states attests to the effectiveness of witness protection: the United States Marshal Service boast of never having lost a witness placed in their care post-trial. ${ }^{89}$ If such witness protection can be achieved in the United States, without damage to the fairness of the trial process, why has such a measure not been considered in England and Wales?

The Lord Chief Justice Sir Igor Judge has cast doubt, firstly in the Court of Appeal hearing of Davis and, more recently, in the appeal of Mayers, on the value of expanding witness protection in England and Wales. His Lordship, in his judgment in Mayers found that there was a "degree of unreality about the submission that witness relocation should normally provide a practicable alternative to an anonymity order." 90 In Davis in 2006 Lord Judge deemed witness protection as "grossly invasive of the right of the witness and his family to private and family life." Yet it is submitted that the rights of the witness which the Lord Chief Justice describes are naturally accompanied by social responsibilities. One such responsibility, that every citizen must bear, is to aid the process of justice and, it follows, uphold the rule of law against those who seek to challenge it through dangerous criminal activity. Whereas the government believes that they can protect the "rights of the innocent" through allowing witnesses anonymity it is submitted that such protection can not be allowed to unfairly handicap those accused of criminal offences, who themselves, it must remembered, are innocent too, until proven guilty.

The unfortunate reality of the situation is the same as in many other spheres of the administration of justice in the present day: the answer is found in the cost. There is no doubt that a well-equipped witness protection service, run by a dedicated agency such as the Marshals in the United States, would require a substantial initial expenditure by the Ministry of Justice, and would add a significant weight year after year to a criminal justice budget which we are regularly told is over-stretched and under pressure. Yet surely it is among

\footnotetext{
89 "No programme participant who follows security guidelines has ever been harmed while under the protection of the Marshalls Service" (http://www.usmarshalls.gov/witsec/index.html) quoted in Justice: Criminal Evidence (Witness Anonymity) Bill. Briefing for the House of Commons (All Stages). July 2008 para [14].

${ }^{90}$ Op cit, at para [9].
} 
the first duties of any government to maintain human rights on an equal footing for all, particularly the right to a fair trial, whatever the cost. The government was forced into a volt face regarding the post 2001 policy of indefinitely detaining foreign terrorist suspects at Belmarsh prison following the House of Lords ruling in A (FC) and others $v$ Secretary of State for the Home Department. ${ }^{91}$ Their Lordships deemed such a policy discriminatory and incompatible with human rights. Following this decision the government was forced to implement the more expensive policy of "control orders" to achieve their policy goal. The same principle applies with witness anonymity: where one policy is incompatible with human rights an alternative must be considered, even if the cost is greater and the convenience considerably less so.

\section{CONCLUSION: PROTECTING WITNESSES AND PROTECTING HUMAN RIGHTS}

The Government maintains that the 2008 Witness Anonymity Act is "consistent with" the requirements of human rights law, and thus the debate as to the use of anonymous testimony is an academic one only. Yet this article has demonstrated the difficulty a defendant is presently placed in under the Act. The defendant presently faced with the prospect of anonymous testimony against him is dependent on prosecution disclosure for the formulation of his defence and subject to the undeniable prejudice he will suffer in the mind of jurors; in granting a witness anonymity the court has decided that the defendant, or his associates, pose a threat before the jury have had chance to consider this prosecution assertion independently.

The Coroners and Justice Bill 2009, at the time of writing, appears to represent a missed opportunity for re-consideration of the 2008 Witness Anonymity Act and of whether depriving the defendant of a completely fair trial before an unequivocally impartial jury is the best way in which the mischief of witness intimidation may be combated. It is submitted that the only logical conclusion, that rightly gives due regard to the rights of the accused, is that it is not. Serious consideration must be given to genuine witness protection programme for England and Wales. Citizens who may become witnesses have social duties as well as human rights and the police and prosecution service would do well to offer this assertion before making an offer of trial anonymity. Through witness protection the American authorities have managed to dismantle large sections of the New York Mafia, without

${ }^{91}$ A(FC) and others $v$ Secretary of State for the Home Department [2005] 2 AC 68. Part IV of the Anti-Terrorism, Crime and Security Act 2001 deemed incompatible with the Human Rights Act 1998 as it permitted indefinite detention for foreign nationals but not British citizens. 


\section{COURTS}

interference with the trial process or with rights of the accused. ${ }^{92}$ Short of this approach, the New Zealand model, where independent counsel assesses need for anonymous evidence and the risk of untruthful testimony, is a bare minimum requirement if the right to a fair trial is to be maintained. Yet such a standard - the bear minimum to protect a fundamental human right - should not be the sum of what we aspire to.

This article has sough to demonstrate that the debate about how best to protect witnesses giving testimony in criminal trials cannot be deemed over, even with the passage of the Coroners and Justice Bill. Witness anonymity need not be a fait accompli. The arguments against anonymous testimony in our courts must be seized again by those in Parliament who wish to see the right to a fair trial, and the achievement of open justice, remain fundamental and absolute tenets of English criminal justice not mere considerations to be balanced with the present deemed needs of public policy. The fact remains that the particular public policy the government has in mind can be achieved without such a challenge to justice as presently stands enacted.

92 Clive Coleman “Can Justice Afford Witness Anonymity?" in The Times: http://www.timesonline.co.uk/tol/comment/columnists/guest_contributors/article4192 851.ece. 